\title{
Influence of Leaf-fruit Ratio and Nitrogen Rate on Fruit Characteristics, Nitrogenous Compounds, and Nonstructural Carbohydrates in Young Persimmon Trees
}

\author{
Seong-Tae Choi ${ }^{1}$ and Doo-Sang Park \\ Sweet Persimmon Research Institute, Gyeongnam Agricultural Research and \\ Extension Services, Gimhae 621-802, Republic of Korea \\ Seong-Mo Kang \\ Department of Horticulture, Institute of Agriculture and Life Sciences, \\ Gyeongsang National University, Jinju 660-701, Republic of Korea
}

\author{
Seong-Koo Kang \\ Department of Pomology, Korea National College of Agriculture and \\ Fisheries, Hwaseong 445-760, Republic of Korea
}

Additional index words. Diospyros kaki, fruit load, amino acid, protein, soluble sugar, starch

\begin{abstract}
The effects of fruit load and nitrogen (N) rate $(0,20$, and $40 \mathrm{~g} \mathrm{~N}$ per tree) on fruit characteristics and the composition of nitrogenous compounds (e.g., amino acids and protein) and nonstructural carbohydrates in different plant tissues were determined in container-grown 5-year-old ' $F u y u$ ' persimmon trees. Leaf-fruit $(\mathrm{L} / \mathrm{F})$ ratios were adjusted to either 20 (high) or 10 (low) by fruit thinning on 2 July. $\mathbf{N}$ was applied by fertigation as $1 \%(w / v)$ urea from 3 July to 20 Sept. The low $\mathrm{L} / \mathrm{F}$ ratio decreased size and coloration of fruits, whereas increasing $\mathrm{N}$ rate resulted in fruits with low skin color and soluble solids but with high firmness. The high $\mathrm{L} / \mathrm{F}$ ratio increased $\mathrm{N}$ concentrations only in 1- to 4-year-old wood and the trunk, whereas increasing $N$ rate increased $N$ concentrations of all tree tissues, especially of roots. The $\mathrm{L} / \mathrm{F}$ ratio did not significantly affect the composition of nitrogenous compounds and carbohydrates in the tree tissues. As $\mathbf{N}$ rate increased, amino acid concentrations increased in all the tree parts, especially in aerial wood and roots where a three- to eightfold increase was observed between the 0 - and $40-\mathrm{g} N$ rates. Although not great, protein concentrations also increased with increasing $\mathbf{N}$ rate. Increasing $\mathbf{N}$ rate significantly reduced soluble sugars in fruit, trunk, and root and starch in leaf and root. The results indicated that an excessive supply of supplemental $N$ could delay fruit maturation and reduce carbohydrate accumulations of 'Fuyu' trees regardless of the $L / F$ ratios.
\end{abstract}

Nitrogen application affects the production and quality of persimmon fruits. Low $\mathrm{N}$ availability during the growing season often results in small-sized fruits but with better coloration (Choi et al., 2008; George et al., 1997; Park, 2002). In contrast, a high N availability helps fruit growth but may inhibit fruit coloration depending on the time of its application (Agustí et al., 2004; Choi et al., 2008, 2009; Park, 2002). The poor fruit coloration often becomes a severe problem for latematuring persimmon cultivars such as 'Fuyu' in the southern region of Korea. Growers often have to wait for color development, during

\footnotetext{
Received for publication 11 May 2011. Accepted for publication 17 Jan. 2012.

We gratefully acknowledge the financial support provided by the Rural Development Administration, Republic of Korea.

${ }^{1}$ To whom reprint requests should be addressed; e-mailstchoi1234@korea.kr.
}

which a hard frost may ruin the fruits of the year.

In general, maintaining low fruit load is favorable for the production of quality fruit, whereas high fruit load is desirable for the maximum yield. For producing quality persimmon fruits, it has been recommended to leave one or two flower buds on a bearing shoot before flowering and to thin fruits after the June drop to maintain the $\mathrm{L} / \mathrm{F}$ ratio at $\approx 20$ (Choi et al., 2010). However, some persimmon growers have kept a low $\mathrm{L} / \mathrm{F}$ ratio of $\approx 10$ after June drop to increase yield. Increasing fruit load can reduce size, soluble solids, and coloration of the fruits (Choi et al., 2010; Palmer et al., 1997; Wünsche and Ferguson, 2005). High fruit-load trees are prone to alternate bearing, especially when their vigor is low. All of these drawbacks are exacerbated further by the inadequate availability of N (Forshey and Elfving, 1989; George et al., 1997; Wünsche and Ferguson, 2005). Supplemental $\mathrm{N}$ application during summer has been recommended in Korea for supporting tree vigor and flower bud differentiation, and maintaining adequate $\mathrm{N}$ status in the tree can be much more important in the higher fruit-load orchards for ensuring sustainable production of quality fruits.

High fruit loads can also decrease carbohydrate accumulation in perennial tissues of the tree (Choi et al., 2005; Loescher et al., 1990; Wünsche and Ferguson, 2005). N and nonstructural carbohydrates accumulated before leaf fall are of extreme importance for initial growth the next spring, especially so in high fruit-load trees (Choi et al., 2009; Hirata et al., 1974; Kim et al., 2009; Park et al., 2003). The reserve $\mathrm{N}$ compounds are present as amino acids and proteins and the reserve carbohydrates as soluble sugars and starch (Cheng et al., 2004; Oliveira and Priestley, 1988; Titus and Kang, 1982). A negative relationship exists between $\mathrm{N}$ and carbohydrate concentrations in reserve organs of fruit trees, because $\mathrm{N}$ assimilation consumes carbohydrates for carbon skeletons and energy (Cheng and Fuchigami, 2002; Xia and Cheng, 2004). Accordingly, the level of nonstructural carbohydrates in storage organs may be reduced by the increase in $\mathrm{N}$ supply, but such a cause-and-effect relationship on a whole tree basis has yet to be demonstrated in persimmon, especially under different fruit-load conditions. This study was conducted to determine the combined effects of fruit loads and $\mathrm{N}$ fertigation rates on fruit characteristics and the interdependence between nitrogenous compounds and carbohydrates in young persimmon trees.

\section{Materials and Methods}

Tree management. Five-year-old trees of 'Fuyu' persimmon (Diospyros kaki) were used in this experiment. After grafting on seedlings, the trees had been grown for 1 year at a nursery at the Sweet Persimmon Research Institute in Gimhae, Korea. They were then transplanted into 70-L containers, filled with sandy loam soil, and spaced at $1.5 \mathrm{~m} \times$ $1 \mathrm{~m}$ aboveground. The trees received compound fertilizers containing macronutrients and micronutrients until they were 5 years old for this study. Trees were supplied in the previous year with $\approx 18 \mathrm{~g}$ of $\mathrm{N}, 5 \mathrm{~g}$ of phosphorus (P), $15 \mathrm{~g}$ of potassium $(\mathrm{K}), 4 \mathrm{~g}$ of calcium $(\mathrm{Ca})$, and $2 \mathrm{~g}$ of magnesium $(\mathrm{Mg})$. No nutrient-related disorders were visibly indicated in the leaves and fruits of the trees. For this experiment, 36 trees with similar size were selected and their flower buds were thinned in mid-May to one or two buds per bearing shoot, leaving 40 to 60 flower buds per tree. Extension growth of the shoots stopped in late May and leaf expansion stopped in late June. Commercial fertilizers containing a total of $5.2 \mathrm{~g}$ of P, $19.2 \mathrm{~g}$ of $\mathrm{K}$, $4.3 \mathrm{~g}$ of $\mathrm{Ca}$, and $2.3 \mathrm{~g}$ of $\mathrm{Mg}$ were used to fertigate each container by soil-surface application at 2-week intervals from June to September in the experimental year. Trickle irrigation was adjusted to deliver 1 to $6 \mathrm{~L}$ of underground water per container a day, starting 
at $1 \mathrm{~L}$ in early spring, gradually increasing to $6 \mathrm{~L}$ in midsummer, and then decreasing to $3 \mathrm{~L}$ at the end of the experiment.

Treatments. The treatment was arranged in a two $\times$ three factorial design with six single-tree replicates. Treatments consisted of two $\mathrm{L} / \mathrm{F}$ ratios and three $\mathrm{N}$ rates applied by fertigation. When physiological fruit drop was finished $\approx 23$ June, the number of leaves and fruits in a tree was counted from 27 June to 1 July. On 2 July (37 d after full bloom), the $\mathrm{L} / \mathrm{F}$ ratio was adjusted to 20 (high) and 10 (low) by fruit thinning to maintain the number of fruits per tree at $\approx 20$ and 40 until harvest, respectively. Average fresh weight of the thinned fruits was $14 \mathrm{~g}$ when the $\mathrm{L} / \mathrm{F}$ treatment was performed. Three $\mathrm{N}$ rates, 0 , 20 , and $40 \mathrm{~g}$ in total amounts per tree, were supplied by fertigation as $1 \%(\mathrm{w} / \mathrm{v})$ urea at 3 - to 4-d intervals from 3 July to 20 Sept. when N absorption from the root is active (Fukui et al., 1999). The 20-g N rate per tree is the $\mathrm{N}$ amount routinely used to grow similar-sized trees without disorders at the Research Institute. All trees from $\mathrm{L} / \mathrm{F}$ ratio and $\mathrm{N}$ rate treatments were assigned in a completely randomized design. Shoot regrowth after the treatments was rarely found and it was immediately removed.

Sampling and data collection. Fruits were harvested on 31 Oct. Fifteen fruits per tree were randomly sampled and used to evaluate their characteristics. Fruit skin color was measured as Hunter $a$ values using a colorimeter (CM-508i, Minolta Co., Osaka, Japan). A texture analyzer (TA-XT2; Stable Micro Systems Ltd., Surrey, U.K.) equipped with a 5-mm plunger was used to measure the firmness. Fruit juice was collected from sliced mesocarps with a hand presser, and soluble solids were determined using a digital refractometer with an accuracy of $\pm 0.2 \%$ (N1; Atago Co., Tokyo, Japan). On 3 Nov., the whole trees were excavated and divided into leaves, aerial woods, and roots. Aerial woods were separated into shoots, 1- to 4-year-old branches, and the trunk, whereas roots were divided according to their diameter (in $\mathrm{mm}$ ) into fine (2 or less), medium (greater than 2.1 and 10 or less), and large ones (greater than 10.1).

Biochemical analysis. Subsamples of fruit flesh, leaves, aerial woods, and the roots were dried at $80{ }^{\circ} \mathrm{C}$ for $48 \mathrm{~h}$ and then ground with a Wiley mill (3383-L10; Thomas Scientific, Swedesboro, NJ) to pass through a 20-mesh screen. Total $\mathrm{N}$ concentration was analyzed with a Kjeldahl instrument (Kjeltec 2300; Foss Co., Höganäs, Sweden) by using the microKjeldahl method (Nelson and Sommers, 1973). Concentrations of soluble sugars and starch were measured as described by McCready et al. (1950), whereas those of amino acids and proteins were determined by ninhydrin assay (Yemm and Cocking, 1955) and the method of Bradford (1976), respectively. The standards used for the analyses were: glucose for carbohydrates, L-leucine for amino acids, and bovine serum albumin for proteins.

Experiment design and statistical analysis. Treatments were arranged in a factorial design with six replications for each treatment. Treatment includes L/F ratios in two levels (20 and
$10)$ and $\mathrm{N}$ rates in three levels $(0,20$, and $40 \mathrm{~g})$. Treatment effects and their interactions were identified by analysis of variance (ANOVA) using the general linear model procedure of SAS Version 8.1 (SAS Institute, Inc., Cary, NC). The means were separated using the Duncan's multiple range test at $P \leq 0.05$.

\section{Results}

Fruit weight was significantly affected by the $\mathrm{L} / \mathrm{F}$ ratio but not by the $\mathrm{N}$ rate within a given ratio (Table 1). Average fruit weight was $193 \pm 2 \mathrm{~g}$ in the trees with an $\mathrm{L} / \mathrm{F}$ ratio of 20 , and it decreased to $165 \pm 2 \mathrm{~g}$ in the trees with an $\mathrm{L} / \mathrm{F}$ ratio of 10 . The result of ANOVA indicated that the low $\mathrm{L} / \mathrm{F}$ ratio delayed coloration of fruit skin. Fertigating trees decreased skin color and soluble solids at both $\mathrm{L} / \mathrm{F}$ ratios. Fertigation increased firmness at $\mathrm{L} / \mathrm{F} 20$ and trees with an $\mathrm{L} / \mathrm{F}$ ratio of 10 had the greatest firmness when grown with the $20-\mathrm{g}$ N rate. Soluble solids at the L/F ratio of 20 and 10 were both $17.7^{\circ}$ Brix for the $0 \mathrm{~g} \mathrm{~N}$ but decreased to 15.9 and $16.3{ }^{\circ}$ Brix for the $40 \mathrm{~g} \mathrm{~N}$, respectively.

As a result of ANOVA, the $\mathrm{L} / \mathrm{F}$ ratios affected $\mathrm{N}$ concentrations only in 1- to 4-year-old wood and the trunk, in which $\mathrm{N}$ concentrations were lower in trees with $\mathrm{L} / \mathrm{F}$ ratio of 10 than in trees with the ratios of 20 (Table 2). The increase of $\mathrm{N}$ concentrations in the tree tissues tended to be greater when the $\mathrm{N}$ rate increased from 0 to $20 \mathrm{~g}$ than from 20 to $40 \mathrm{~g}$. There were notable changes in $\mathrm{N}$ concentrations in response to $\mathrm{N}$ rate in the roots, especially in medium roots: the $40 \mathrm{~g} \mathrm{~N}$ increased $\mathrm{N}$ concentration more than threefold compared with that of $0 \mathrm{~g} \mathrm{~N}$ at both $\mathrm{L} / \mathrm{F}$ ratios.

Amino acid and protein concentrations of the tree tissues were unaffected by the $\mathrm{L} / \mathrm{F}$ ratios (Table 3 ). The response of amino acids to $\mathrm{N}$ rate was significant in all the tree tissues except the leaves. It was noted that shoot amino acids increased at the $\mathrm{L} / \mathrm{F}$ ratio of 20 more than the ratio of 10 when $\mathrm{N}$ rate increased from $20 \mathrm{~g}$ to $40 \mathrm{~g}$. There were three- to eightfold differences of amino acid concentrations in aerial woods and roots between the 0 - and $40-\mathrm{g} \mathrm{N}$ rates. As were observed for $\mathrm{N}$ concentrations (Table 2), the extent of increase in the tree tissues tended to be more between the 0 - and $20-\mathrm{g} \mathrm{N}$ rates than between the 20 - and $40-\mathrm{g} \mathrm{N}$ rates. Fertigating trees significantly increased protein concentrations in fruit flesh, shoot, trunk, and large roots

Table 1. Effect of leaf/fruit ratios and nitrogen $(\mathrm{N})$ rates on fruit characteristics of 'Fuyu' persimmon. ${ }^{\mathrm{z}}$

\begin{tabular}{|c|c|c|c|c|c|}
\hline \multicolumn{2}{|c|}{ Treatment } & \multirow[b]{2}{*}{ Avg wt (g) } & \multirow{2}{*}{$\begin{array}{l}\text { Skin color } \\
\text { (Hunter } a \text { ) }\end{array}$} & \multirow[b]{2}{*}{ Firmness $(N)$} & \multirow{2}{*}{$\begin{array}{c}\text { Soluble } \\
\left.\text { solids ( }{ }^{\circ} \text { Brix }\right)\end{array}$} \\
\hline$\overline{\text { Leaf/fruit ratio }}$ & $\mathrm{N}$ rate $(\mathrm{g} /$ tree $)$ & & & & \\
\hline \multirow{3}{*}{20} & 0 & $193 \mathrm{a}^{\mathrm{y}}$ & $29.3 \mathrm{a}$ & $18.3 \mathrm{c}$ & $17.7 \mathrm{a}$ \\
\hline & 20 & $195 \mathrm{a}$ & $23.6 \mathrm{~b}$ & $23.4 \mathrm{a}$ & $16.5 \mathrm{~b}$ \\
\hline & 40 & $191 \mathrm{a}$ & $21.3 \mathrm{bc}$ & $22.3 \mathrm{a}$ & $15.9 \mathrm{~b}$ \\
\hline \multirow[t]{3}{*}{10} & 0 & $163 \mathrm{~b}$ & $28.1 \mathrm{a}$ & $20.3 \mathrm{~b}$ & $17.7 \mathrm{a}$ \\
\hline & 20 & $167 \mathrm{~b}$ & $22.0 \mathrm{bc}$ & $20.4 \mathrm{~b}$ & $15.8 \mathrm{~b}$ \\
\hline & 40 & $162 \mathrm{~b}$ & $19.7 \mathrm{c}$ & $23.6 \mathrm{a}$ & $16.3 \mathrm{~b}$ \\
\hline \multicolumn{6}{|l|}{ Significance } \\
\hline \multicolumn{2}{|c|}{ Leaf/fruit ratio $(\mathrm{L})$} & ** & * & NS & NS \\
\hline \multicolumn{2}{|l|}{$\mathrm{N}$ rate $(\mathrm{N})$} & NS & ** & ** & ** \\
\hline \multicolumn{2}{|l|}{$\mathrm{L} \times \mathrm{N}$} & NS & NS & ** & NS \\
\hline
\end{tabular}

${ }^{\mathrm{z}}$ Fruits were harvested on 31 Oct.

${ }^{y}$ Means within a column with the same letter are not significantly different by Duncan's multiple range test at $P \leq 0.05$.

NS $=$ nonsignificant; *significant at $P \leq 0.05 ; *$ significant at $P \leq 0.01$.

Table 2. Effect of leaf/fruit ratios and nitrogen $(\mathrm{N})$ rates on concentrations of nitrogen in different tissues of 5 -year-old 'Fuyu' persimmon. ${ }^{2}$

\begin{tabular}{|c|c|c|c|c|c|c|c|c|c|}
\hline \multicolumn{2}{|c|}{ Treatment } & \multirow[b]{3}{*}{ Leaf } & \multirow[b]{3}{*}{ Fruit flesh } & \multirow{2}{*}{\multicolumn{3}{|c|}{ Aerial wood }} & \multirow{2}{*}{\multicolumn{3}{|c|}{ Root }} \\
\hline \multirow{2}{*}{$\begin{array}{l}\text { Leaf/fruit } \\
\text { ratio }\end{array}$} & \multirow{2}{*}{$\begin{array}{l}\text { N rate } \\
(\mathrm{g} / \text { tree })\end{array}$} & & & & & & & & \\
\hline & & & & Shoot & 1 to $4 \mathrm{yr}$ old & Trunk & Fine & Medium & Large \\
\hline & & \multicolumn{8}{|c|}{ Nitrogen $(\% D W)$} \\
\hline \multirow[t]{3}{*}{20} & 0 & $1.32 \mathrm{c}^{\mathrm{y}}$ & $0.36 \mathrm{~cd}$ & $0.64 \mathrm{~b}$ & $0.51 \mathrm{~d}$ & $0.44 \mathrm{c}$ & $0.94 \mathrm{c}$ & $0.53 \mathrm{~d}$ & $0.49 \mathrm{c}$ \\
\hline & 20 & $1.79 \mathrm{~b}$ & $0.44 \mathrm{ab}$ & $1.07 \mathrm{a}$ & $0.95 \mathrm{bc}$ & $0.81 \mathrm{ab}$ & $1.68 \mathrm{ab}$ & $1.22 \mathrm{c}$ & $1.04 \mathrm{~b}$ \\
\hline & 40 & $2.13 \mathrm{a}$ & $0.47 \mathrm{ab}$ & $1.24 \mathrm{a}$ & $1.05 \mathrm{a}$ & $0.86 \mathrm{a}$ & $1.87 \mathrm{a}$ & $1.60 \mathrm{a}$ & $1.26 \mathrm{a}$ \\
\hline \multirow[t]{3}{*}{10} & 0 & $1.26 \mathrm{c}$ & $0.32 \mathrm{~d}$ & $0.67 \mathrm{~b}$ & $0.47 \mathrm{~d}$ & $0.40 \mathrm{c}$ & $0.93 \mathrm{~d}$ & $0.46 \mathrm{~d}$ & $0.43 \mathrm{c}$ \\
\hline & 20 & $1.99 \mathrm{ab}$ & $0.42 \mathrm{bc}$ & $1.18 \mathrm{a}$ & $0.90 \mathrm{c}$ & $0.74 \mathrm{~b}$ & $1.46 \mathrm{~b}$ & $1.23 \mathrm{c}$ & $1.01 \mathrm{~b}$ \\
\hline & 40 & $2.03 \mathrm{ab}$ & $0.50 \mathrm{a}$ & $1.10 \mathrm{a}$ & $1.01 \mathrm{ab}$ & $0.84 \mathrm{a}$ & $1.80 \mathrm{a}$ & $1.41 \mathrm{~b}$ & $1.12 \mathrm{ab}$ \\
\hline
\end{tabular}

Significance

\begin{tabular}{lllllllll} 
Leaf/fruit ratio (L) & NS & NS & NS & $*$ & $*$ & NS & NS & NS \\
$\mathrm{N}$ rate (N) & $* *$ & $* *$ & $* *$ & $* *$ & $* *$ & $* *$ & $* *$ & $* *$ \\
$\mathrm{~L} \times \mathrm{N}$ & NS & NS & NS & NS & NS & NS & NS & NS \\
\hline
\end{tabular}

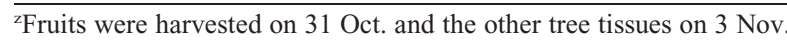

${ }^{y}$ Means within a column with the same letter are not significantly different by Duncan's multiple range test at $P \leq 0.05$.

NS $=$ nonsignificant; * significant at $P \leq 0.05 ; * *$ significant at $P \leq 0.01$.

DW $=$ dry weight. 
(Table 3). $\mathrm{N}$ fertigation had no influence on protein concentrations in 1- to 4-year-old wood at an $\mathrm{L} / \mathrm{F}$ ratio of 20 . In contrast, trees fertigated with $40 \mathrm{~g} \mathrm{~N}$ at an $\mathrm{L} / \mathrm{F}$ ratio of 10 had greater protein concentrations in 1- to 4year-old wood than unfertigated trees.

The L/F ratios did not significantly alter the concentration of soluble sugars in tree tissues (Table 4). However, Increasing $\mathrm{N}$ rate tended to decrease soluble sugars in fruit flesh, trunk, and all the roots. Soluble sugar concentrations in the roots were, on average, $13.9 \%$ in $0 \mathrm{~g} \mathrm{~N}$ trees and they decreased to $9.6 \%$ in $40 \mathrm{~g} \mathrm{~N}$ trees at both $\mathrm{L} / \mathrm{F}$ ratios. Fertigating trees with $\mathrm{N}$ decreased starch concentrations in fine roots at both $\mathrm{L} / \mathrm{F}$ ratios and decreased starch concentrations in leaves at an L/F ratio of 20. When $\mathrm{N}$ rate increased from $0 \mathrm{~g}$ to $40 \mathrm{~g}$, leaf starch decreased from $7.6 \%$ to $4.5 \%$ in trees with an $\mathrm{L} / \mathrm{F}$ ratio of 20 .

\section{Discussion}

High fruit load has been known to decrease size, coloration, and soluble sugars in fruits as well as carbohydrate accumulations in perennial parts of fruit trees (Choi et al., 2005; Loescher et al., 1990; Wünsche and Ferguson, 2005). However, fruit load only influenced on average fruit weight and skin color in this experiment. The different effect from the previous results suggests that the response of persimmon trees to fruit load may differ depending on fruit thinning times and environmental and cultural conditions, in addition to the degree of fruit load (Forshey and Elfving, 1989; Wünsche and Ferguson, 2005). Low coloration, low soluble solids, and high firmness of the fruits by the high $\mathrm{N}$ rate (Table 1) indicated that high $\mathrm{N}$ supply could delay fruit maturation as has been reported for apple (Neilsen et al., 2009; Wargo et al., 2004) and persimmon (Agustí et al., 2004; Choi et al., 2008, 2011a; Park, 2002). Delayed maturation of 'Fuyu' persimmon is often detrimental when the first frost occurs in late October or early November. The greater changes between the 0 - and 20 -g $\mathrm{N}$ rates than between the 20 - and $40-\mathrm{g} \mathrm{N}$ rates could be related to the result that nutrient absorptions in fruits did not proportionally increase with increasing fertilization rate (Choi et al., 2011a).

Choi et al. (2011b) reported that leaf $\mathrm{N}$ concentration decreased from $2.0 \%$ in late September to $1.7 \%$ in early November at 'Fuyu' persimmon orchards producing quality fruits in South Korea. High leaf N concentration of the trees supplied with a high $\mathrm{N}$ rate (Table 2) may imply a delay in leaf senescence and the decrease in the magnitude of $\mathrm{N}$ remobilized to perennial tissues of the tree (Kim et al., 2009). Leaf $\mathrm{N}$ remobilization would be severely curtailed with an early frost. When the $\mathrm{N}$ rate exceeded $20 \mathrm{~g}$ per tree, there was little increase in $\mathrm{N}$ concentration in most tree tissues. Some of the $\mathrm{N}$ from the high rate fertigation might be used for the growth of other vegetative organs or leached out of the containers.

In this study, amino acids were significantly affected by the $\mathrm{N}$ rates in all perennial
Table 3. Effect of leaf/fruit ratios and nitrogen $(\mathrm{N})$ rates on concentrations of amino acids and protein in different tissues of 5-year-old 'Fuyu' persimmon. ${ }^{\mathrm{z}}$

\begin{tabular}{|c|c|c|c|c|c|c|c|c|c|}
\hline \multicolumn{2}{|c|}{ Treatment } & \multirow[b]{3}{*}{ Leaf } & \multirow[b]{3}{*}{ Fruit flesh } & \multicolumn{3}{|c|}{ Aerial wood } & \multirow{2}{*}{\multicolumn{3}{|c|}{ Root }} \\
\hline \multirow{2}{*}{$\begin{array}{l}\text { Leaf/fruit } \\
\text { ratio }\end{array}$} & \multirow{2}{*}{$\begin{array}{l}\text { N rate } \\
(\mathrm{g} / \text { tree })\end{array}$} & & & \multirow{2}{*}{\multicolumn{2}{|c|}{$\begin{array}{c}1 \text { to } 4 \text { years } \\
\text { old }\end{array}$}} & \multirow[b]{2}{*}{ Trunk } & & & \\
\hline & & & & & & & Fine & Medium & Large \\
\hline \multirow{4}{*}{20} & & \multicolumn{8}{|c|}{ Amino acids $(\% D W)$} \\
\hline & 0 & $0.56 \mathrm{a}^{\mathrm{y}}$ & $0.26 \mathrm{~b}$ & $0.24 \mathrm{c}$ & $0.12 \mathrm{c}$ & $0.10 \mathrm{~d}$ & $0.30 \mathrm{c}$ & $0.52 \mathrm{c}$ & $0.67 \mathrm{c}$ \\
\hline & 20 & $0.54 \mathrm{a}$ & $0.36 \mathrm{a}$ & $0.79 \mathrm{~b}$ & $0.75 \mathrm{~b}$ & $0.66 \mathrm{bc}$ & $1.13 \mathrm{~b}$ & $2.51 \mathrm{~b}$ & $2.11 \mathrm{~b}$ \\
\hline & 40 & $0.56 \mathrm{a}$ & $0.39 \mathrm{a}$ & $1.04 \mathrm{a}$ & $0.96 \mathrm{a}$ & $0.84 \mathrm{a}$ & $1.78 \mathrm{a}$ & $3.36 \mathrm{a}$ & $2.82 \mathrm{a}$ \\
\hline \multirow[t]{3}{*}{10} & 0 & $0.51 \mathrm{a}$ & $0.22 \mathrm{~b}$ & $0.28 \mathrm{c}$ & $0.11 \mathrm{c}$ & $0.10 \mathrm{~d}$ & $0.30 \mathrm{c}$ & $0.41 \mathrm{c}$ & $0.51 \mathrm{c}$ \\
\hline & 20 & $0.54 \mathrm{a}$ & $0.37 \mathrm{a}$ & $0.85 \mathrm{~b}$ & $0.69 \mathrm{~b}$ & $0.56 \mathrm{c}$ & $1.01 \mathrm{~b}$ & $2.48 \mathrm{~b}$ & $2.05 \mathrm{~b}$ \\
\hline & 40 & $0.55 \mathrm{a}$ & $0.43 \mathrm{a}$ & $0.86 \mathrm{~b}$ & $0.91 \mathrm{a}$ & $0.75 \mathrm{ab}$ & $1.90 \mathrm{a}$ & $3.20 \mathrm{a}$ & $2.50 \mathrm{ab}$ \\
\hline
\end{tabular}

Significance

\begin{tabular}{|c|c|c|c|c|c|c|c|c|}
\hline Leaf/fruit ratio (L) & NS & NS & NS & NS & NS & NS & NS & NS \\
\hline $\mathrm{N}$ rate $(\mathrm{N})$ & NS & ** & ** & ** & ** & $* *$ & $* *$ & $* *$ \\
\hline $\mathrm{L} \times \mathrm{N}$ & NS & NS & $*$ & NS & NS & NS & NS & NS \\
\hline & \multicolumn{8}{|c|}{ Protein $(\% D W)$} \\
\hline 0 & $1.06 \mathrm{a}$ & $0.63 \mathrm{~b}$ & $0.37 \mathrm{~b}$ & $0.28 \mathrm{~b}$ & $0.16 \mathrm{c}$ & $1.58 \mathrm{a}$ & $0.90 \mathrm{a}$ & $0.51 \mathrm{ab}$ \\
\hline 20 & $1.06 \mathrm{a}$ & $0.73 \mathrm{ab}$ & $0.44 \mathrm{ab}$ & $0.30 \mathrm{ab}$ & $0.24 \mathrm{~b}$ & $1.65 \mathrm{a}$ & $0.99 \mathrm{a}$ & $0.66 \mathrm{a}$ \\
\hline 40 & $0.93 \mathrm{a}$ & $0.65 \mathrm{ab}$ & $0.50 \mathrm{a}$ & $0.27 \mathrm{~b}$ & $0.26 \mathrm{ab}$ & $1.56 \mathrm{a}$ & $1.09 \mathrm{a}$ & $0.61 \mathrm{ab}$ \\
\hline 0 & $1.14 \mathrm{a}$ & $0.62 \mathrm{~b}$ & $0.37 \mathrm{~b}$ & $0.25 \mathrm{~b}$ & $0.17 \mathrm{c}$ & $1.70 \mathrm{a}$ & $0.83 \mathrm{a}$ & $0.48 \mathrm{~b}$ \\
\hline 20 & $1.10 \mathrm{a}$ & $0.77 \mathrm{a}$ & $0.51 \mathrm{a}$ & $0.32 \mathrm{ab}$ & $0.23 \mathrm{~b}$ & $1.71 \mathrm{a}$ & $0.99 \mathrm{a}$ & $0.68 \mathrm{a}$ \\
\hline 40 & $1.00 \mathrm{a}$ & $0.76 \mathrm{a}$ & $0.46 \mathrm{a}$ & $0.36 \mathrm{a}$ & $0.29 \mathrm{a}$ & $1.64 \mathrm{a}$ & $0.89 \mathrm{a}$ & $0.59 \mathrm{ab}$ \\
\hline
\end{tabular}

Significance

$\begin{array}{llllllllc}\text { Leaf/fruit ratio (L) } & \text { NS } & \text { NS } & \text { NS } & \text { NS } & \text { NS } & \text { NS } & \text { NS } & \text { NS } \\ \mathrm{N} \text { rate }(\mathrm{N}) & \text { NS } & * * & * * & \text { NS } & * & \text { NS } & \text { NS } & * \\ \mathrm{~L} \times \mathrm{N} & \text { NS } & \text { NS } & \text { NS } & * & \text { NS } & \text { NS } & \text { NS } & \text { NS }\end{array}$

${ }^{2}$ Fruits were harvested on 31 Oct. and the other tree tissues on 3 Nov.

${ }^{y}$ Means within a column with the same letter are not significantly different by Duncan's multiple range test at $P \leq 0.05$.

NS = nonsignificant; *significant at $P \leq 0.05 ; * *$ significant at $P \leq 0.01$.

$\mathrm{DW}=$ dry weight.

Table 4. Effect of leaf/fruit ratios and nitrogen $(\mathrm{N})$ rates on concentrations of soluble sugars and starch in different tissues of 5-year-old 'Fuyu' persimmon. ${ }^{\mathrm{z}}$

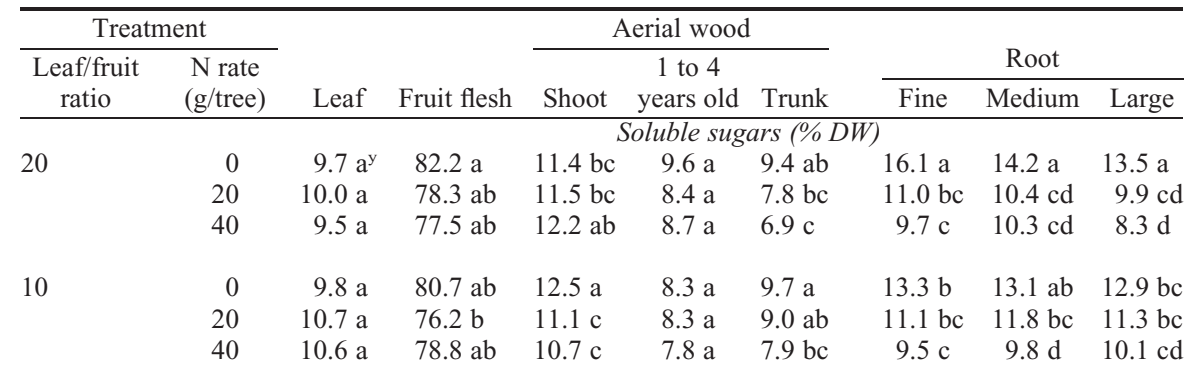

Significance

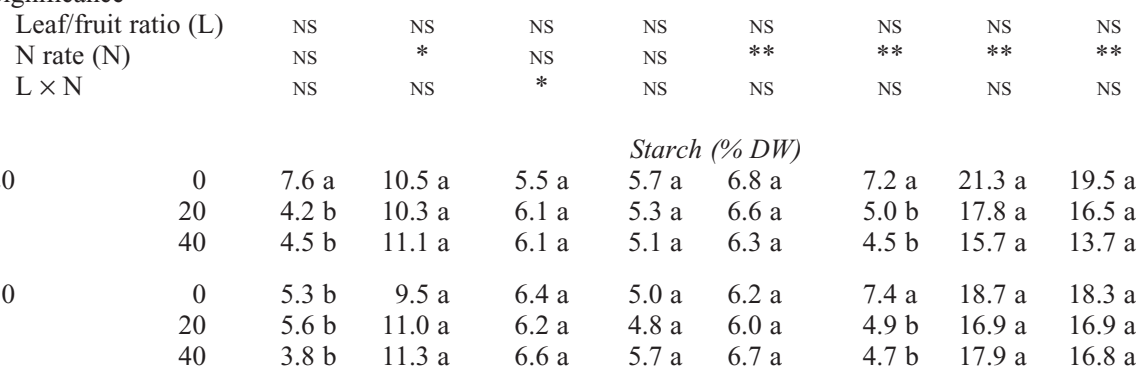

Significance

\begin{tabular}{lllllllll} 
Leaf/fruit ratio (L) & NS & NS & NS & NS & NS & NS & NS & NS \\
N rate (N) & $* *$ & NS & NS & NS & NS & $* *$ & NS & NS \\
$\mathrm{L} \times \mathrm{N}$ & $*$ & NS & NS & NS & NS & NS & NS & NS \\
\hline
\end{tabular}

${ }^{2}$ Fruits were harvested on 31 Oct. and the other tree tissues on 3 Nov.

y Means within a column with the same letter are not significantly different by Duncan's multiple range test at $P \leq 0.05$.

NS = nonsignificant; *significant at $P \leq 0.05 ; * *$ significant at $P \leq 0.01$.

$\mathrm{DW}=$ dry weight. 
parts, whereas proteins were only in some of them (Table 3). The data were consistent with the previous results in that the increase of amino $\mathrm{N}$ by $\mathrm{N}$ supply was more sensitive than that of protein $\mathrm{N}$ in perennial parts of apple (Cheng et al., 2004) and pear (Taylor et al., 1975). Cheng et al. (2004) suggested that the form of soluble amino acids would make $\mathrm{N}$ storage more cost-effective than proteins at high $\mathrm{N}$ supply. The increase in $\mathrm{N}$ reserve plays a significant role for fruit and vegetative growth in the spring of the next season (Kim et al., 2009; Titus and Kang, 1982; Xia and Cheng, 2004). The extent of initial new growth in apple is determined primarily by reserve $\mathrm{N}$ rather than reserve carbohydrates (Cheng and Fuchigami, 2002). Therefore, ensuring a high level of reserve $\mathrm{N}$ during the previous season may become an important strategy to keep the vigor of the trees with high fruit loads. Furthermore, the high N concentration in shoots during summer might lead to more flower bud formation (Choi et al., 2009; Forshey and Elfving, 1989; George et al., 1997), alleviating alternate bearing, which could be a problem under high fruit load.

As $\mathrm{N}$ supply increases, however, more carbon skeletons and energy are needed to incorporate the $\mathrm{N}$ to amino acids and proteins (Cheng and Fuchigami, 2002; Cheng et al., 2004; Titus and Kang, 1982). Increased consumption of carbohydrates for the N metabolism might have led to low soluble sugars in the fruits and low carbohydrate accumulation in reserve organs (Tables 1 and 4). Apple fruits could not color adequately when carbohydrate supply was limited (Walter, 1967). Therefore, excessive $\mathrm{N}$ supply would delay fruit maturation and increase the susceptibility to cold injury of dormant organs. Cold injury of fruit trees was closely related to the extent of carbohydrate accumulation, especially soluble sugars (Layne and Ward, 1978; Oliveira and Priestley, 1988).

There have been reports indicating that high fruit loads decrease carbohydrate concentrations in perennial parts of fruit trees (Choi et al., 2005; Loescher et al., 1990; Wünsche and Ferguson, 2005), but the decrease in this study was not as much as expected even at the $\mathrm{L} / \mathrm{F}$ ratio of 10 . However, high fruit load decreases total carbohydrate content in the perennial organs because of their reduced dry weights (Choi et al., 2005; Loescher et al., 1990). High responsiveness of root soluble sugars to N supply (Table 4 ) suggests that the incorporation of absorbed $\mathrm{N}$ into amino acids occurred mainly in the roots so that the demand for nonstructural carbohydrates in that organ would have been substantial (Titus and Kang, 1982). Because soluble sugars are more easily metabolized than starch, the decrease in the concentrations of the former compounds by increasing $\mathrm{N}$ rate is easily detected (Cheng et al., 2004). In conclusion, despite beneficial roles of high $\mathrm{N}$ reserves, a high rate of $\mathrm{N}$ delays fruit maturation and reduces carbohydrate reserves in persimmon trees. The prudent use of supplemental $\mathrm{N}$ should thus be exercised even under high fruit-load conditions.

\section{Literature Cited}

Agustí, M., M. Juan, A. Martínez-Fuentes, C. Mesejo, and V. Almela. 2004. Calcium nitrate delays climacteric of persimmon fruit. Ann. Appl. Biol. 144:65-69.

Bradford, M.M. 1976. A rapid and sensitive method for the quantization of microgram quantities of protein utilizing the principle of protein-dye binding. Anal. Biochem. 72:248-254.

Cheng, L. and L.H. Fuchigami. 2002. Growth of young apple trees in relation to reserve nitrogen and carbohydrates. Tree Physiol. 22:12971303.

Cheng, L., L.H. Fuchigami, and D. Ranwala. 2004. Nitrogen storage and its interaction with carbohydrates of young apple trees in response to nitrogen supply. Tree Physiol. 24:91-98.

Choi, S.T., G.H. Ahn, Y.C. Lee, and S.M. Kang. 2008. Effect of different autumnal nitrogen application dates on fruit characteristics and storage reserves of 'Fuyu' persimmon. Hort. Environ. Biotechnol. 49:25-29.

Choi, S.T., S.M. Kang, D.S. Park, K.P. Hong, and C.W. Rho. 2011a. Combined effects of leaf/ fruit ratios and $\mathrm{N}$ and $\mathrm{K}$ fertigation levels on growth and distribution of nutrients in potgrown persimmon trees. Sci. Hort. 128:364368 .

Choi, S.T., D.S. Park, S.M. Kang, and S.J. Park. 2011b. Use of a chlorophyll meter to diagnose nitrogen status of 'Fuyu' persimmon leaves. HortScience 46:821-824.

Choi, S.T., D.S. Park, Y.C. Cho, and S.M. Kang. 2009. Tree responses of 'Fuyu' persimmon to urea nitrogen applied at different times during the late season. Acta Hort. 833:307-311.

Choi, S.T., D.S. Park, S.M. Kang, and Y.C. Cho. 2010. Effect of fruit-load on the growth, absorption, and partitioning of inorganic nutrients in young 'Fuyu' persimmon trees. Sci. Hort. 126 : 408-412.

Choi, S.T., D.S. Park, W.D. Song, and S.M. Kang. 2005. Effect of thinning degrees on fruit characteristics and carbohydrate accumulations of persimmon trees defoliated in early autumn. Acta Hort. 685:105-112.

Forshey, C.G. and D.C. Elfving. 1989. The relationship between vegetative growth and fruiting in apple trees. Hort. Rev. 11:229-287.

Fukui, H., Y. Suzuki, E. Ogawa, K. Hirata, Y. Matsubara, and M. Nakamura. 1999. Nitrogen uptake by three- to four-year-old potted trees of Japanese persimmon 'Nishimurawase'. J. Jpn. Soc. Hort. Sci. 68:578-584.

George, A.P., A.D. Mowat, R.J. Collins, and M. Morley-Bunker. 1997. The pattern and control of reproductive development in non-astringent persimmon (Diospyros kaki L.): A review. Sci. Hort. 70:93-122.

Hirata, N., S. Hayashi, and H. Kurooka. 1974. Physiological studies of developing and ripening fruits of the Japanese persimmon. II. The effects of degrees or times of artificial defoliation during last fall on cell division and cell enlargement during the development of fruit, fruit size and fruit quality at maturity. Bull. Faculty of Agr. Tottori Univ. 26:15-27.

Kim, Y.K., C.S. Lim, S.M. Kang, and J.L. Cho. 2009. Root storage of nitrogen applied in autumn and its remobilization to new growth in spring of persimmon trees (Diospyros kaki cv. Fuyu). Sci. Hort. 119:193-196.

Layne, R.E.C. and C.M. Ward. 1978. Rootstock and seasonal influences on carbohydrate levels and cold hardiness of Redhaven peach. J. Amer. Soc. Hort. Sci. 103:408-413.

Loescher, W.H., T. McCamant, and J.D. Keller. 1990. Carbohydrate reserves, translocation, and storage in woody plant roots. HortScience $25: 274-281$

McCready, R.M., J. Guggolz, V. Silviera, and H.S. Owens. 1950. Determination of starch and amylose in vegetables. Anal. Chem. 22: $1156-1158$

Neilsen, G.H., D. Neilsen, and L. Herbert. 2009. Nitrogen fertigation concentration and timing of application affect nitrogen nutrition, yield, firmness, and color of apples grown at high density. HortScience 44:1425-1431.

Nelson, D.W. and L.E. Sommers. 1973. Determination of total nitrogen in plant material. Agron. J. 65:109-112.

Oliveira, C.M. and A. Priestley. 1988. Carbohydrate reserves in deciduous fruit trees. Hort Rev. 10:403-430.

Palmer, J.W., R. Giuliani, and H.M. Adams. 1997. Effect of crop load on fruiting and leaf photosynthesis of 'Braeburn'/M.26 apple trees. Tree Physiol. 17:741-746.

Park, S.J. 2002. Effect of irrigation and N levels on fruit quality and nutrient distribution in 'Fuyu' persimmon tree parts during the final stages of fruit growth. J. Korean Soc. Hort. Sci. 43:321325.

Park, S.J., Y.G. Kim, J.C. Kim, J.L. Cho, B.R. Jeong, S.M. Kang, and Y.C. Lee. 2003. Changes in organic nutrients of senescing Fuyu leaves at two locations differing in the time of abscission. Acta Hort. 601:73-78.

Taylor, B.K., B. van den Ende, and R.L. Canterford. 1975. Effects of rate and timing of nitrogen applications on the performance and chemical composition of young pear trees, cv. Williams' Bon Chrétien. J. Hort. Sci. 50:29-40.

Titus, J.S. and S.M. Kang. 1982. Nitrogen metabolism, translocation and recycling in apple trees. Hort. Rev. 4:204-246.

Walter, T.E. 1967. Factors affecting colour in apples: A review of world literature. Annu. Rpt. E. Malling. Res. Sta. 1966:70-82.

Wargo, J.M., I.A. Merwin, and C.B. Watkins 2004. Nitrogen fertilization, midsummer trunk girdling, and AVG treatments affect maturity and quality of 'Jonagold' apples. HortScience 39:493-500.

Wünsche, J.N. and I.B. Ferguson. 2005. Crop load interactions in apple. Hort. Rev. 31:231-290.

Xia, G. and L. Cheng. 2004. Foliar urea application in the fall affects both nitrogen and carbon storage in young 'Concord' grapevines grown under a wide range of nitrogen supply. J. Amer. Soc. Hort. Sci. 129:653-659.

Yemm, E.W. and E.C. Cocking. 1955. The determination of amino acids with ninhydrin. Analyst (Lond.) 80:209-213. 